\title{
Influence of the Printing Process on The Quality of AGX Printing Plates
}

\author{
Cigula, T.; Mahovic PoljaceK, S. \& Gojo, M.
}

Abstract: One of the most important features in lithography is the stability of the printing plates during the printing process. It is highly influenced by the consistency and the wear of the photoactive coating and aluminium oxide layer. In this research the mechanical properties of the silver halide photoactive coating were observed by measuring coverage value on the printing plates before and after the printing process. The results have shown that the wear of silver halide layer is not significant, but is visible after 80000 prints made. Observing of the stability of the plates was expanded by analyzing the physical and chemical characteristics of aluminium oxide layer. The results have shown that there has been a significant difference in free surface energy and its polar and dispersive components on the printing plates after the print run in regard to used printing ink. This is the reason why mechanical, chemical and physical characteristics of printing plates and other materials used in printing reproduction need to be observed simultaneously.

Key words: lithography, printing plates, quality, stability
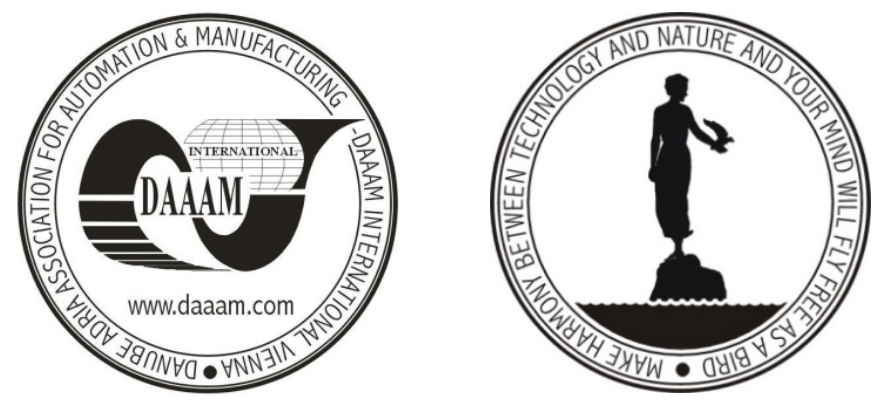

Authors' data: Teaching Assistant Dipl.-Ing. Cigula, T[omislav]; Ass. Prof. Dr. Sc. Mahovic Poljacek, S[anja]; Prof. Dr. Sc. Gojo, M[iroslav], University of Zagreb, Faculty of Grapic Arts, Getaldiceva 2, 10000, Zagreb, Croatia, tomislav.cigula@grf.hr, smahovic@grf.hr,mgojo@grf.hr

This Publication has to be referred as: Cigula, T[omislav]; Mahovic Poljacek, S[anja] \& Gojo, M[iroslav] (2009). Influence of the Printing Process on the Quality of AGX Printing Plates, Chapter 87 in DAAAM International Scientific Book 2009, pp. 897-906, B. Katalinic (Ed.), Published by DAAAM International, ISBN 978-3901509-69-8, ISSN 1726-9687, Vienna, Austria

DOI: $10.2507 /$ daaam.scibook.2009.87 